\title{
The economic impact of oil spill on communities in Imo State and the Niger Delta Region of Nigeria
}

\author{
Alphonsus O. Isidiho ${ }^{1}$, Nik Ahmad Sufian Burhan ${ }^{2 *}$, Mohammad Shatar Sabran ${ }^{3}$, \\ Ahmad Tarmizi Talib ${ }^{4} \&$ Mohd Ibrani Shahrimin Adam Assim ${ }^{5}$ \\ ${ }^{1,2,5}$ Department of Social and Development Sciences, Faculty of Human Ecology. \\ Universiti Putra Malaysia. \\ ${ }^{3}$ Universiti Pendidikan Sultan Idris, Tanjong Malim, Malaysia. \\ ${ }^{4}$ Department of Politics and Government, Faculty of Human Ecology. Universiti Putra Malaysia. \\ *E-mail: nikahmadsufian@upm.edu.my
}

DOI: https://doi.org/10.37134/ejoss.vol6.2.2.2020

Received: 22 May 2020; Accepted: 07 October 2020; Published: 07 October 2020

Cite this paper (APA): Isidiho, A. O., Burhan, N. A. S., Sabran, M. S., Talib, A. T., \& Adam Assim, M. I. S. (2020). The economic impact of oil spill on communities in Imo State and the Niger Delta Region of Nigeria. EDUCATUM Journal of Social Sciences, 6(2), 10-24. https://doi.org/10.37134/ejoss.vol6.2.2.2020

\begin{abstract}
The study examines the economic impacts of oil spill on the life of the people of Ohaji/Egbema and Oguta Communities in Imo State Nigeria. The oil spill has polluted the rivers making it difficult to fish; the spills on farms have destroyed the crops leading to low yield and income, and this caused socioeconomic problems in these communities. The oil spill in these communities are peculiar as it occurs both on water and land unlike other spill in other countries occurring only on water. Literature shows that oil spill worldwide caused severe economic impact including loss of income, drop in share prices, loss of funds through clean-up and remediation, and payments for injurious harm to businesses and environment. The Environmental Kuznets Curve (EKC) theory and stakeholders' theory are useful in this study. The international laws on oil spill compensation have not been adequate, hence compelling countries to invoke their national laws. Using mixed methods, the findings of the study show that the income of these communities was negatively affected and little or no compensation paid to the affected communities. Inadequate enforcement of oil spill laws in Nigeria coupled with lack of political will to strictly enforce these laws has been identified. The spill caused psychological trauma and stress, occupational displacement, decrease in income, poverty and diseases in these communities. There is a need to amend the international laws on oil spill covering both spill from ship and on land, and the urgent need for all related agencies in Nigeria to be active in their duties. The oil companies need to be proactive in addressing the problems created by oil spill, while urgent clean-up and adequate compensations need to be paid.
\end{abstract}

Keywords: oil spill, economic impact, clean-up, compensation, occupational displacement

\section{INTRODUCTION}

The study on the economic impact of oil spill on the communities of Ohaji/Egbema and Oguta in Imo state Nigeria was conducted putting into consideration the micro and macro-economic impacts. The community being an agriculturally based community relied heavily on crop farming and fishing as their major sources of income while other sectors like trading, craftmanship, rural transportation and others provide additional income for few people in those sectors. This made the oil spill have strong and significant negative impact on their economic life and wellbeing. In Imo State and the Niger Delta region, spill have caused deaths, destruction of farmlands, and extermination of fishing business, destruction and pollution of the environment, negative socioeconomic and cultural impacts leading to devastating poverty as the communities depend on the natural environment for their livelihood. The economic impact of spill is highly related to the social impacts as its impact on tourism and hospitality industries causes reduction in jobs, increase in poverty and decrease in revenue (Cheong, 2012). 
Economic impacts of oil spill holistically include cost of clean-up and compensation, damage to agricultural lands, fishery and wildlife and other social and environmental cost (Okonkwo, 2014). The aggregation of these cost and the multiplier effects make the cost of oil spill unestimatable.

Similarly, the spill in Imo State and the Niger Delta region has created lots of social disunity among the communities which have led to inter and intra community wars. Economic impacts of oil spills encompass cost of damage to agricultural lands, fishery and wildlife, cost of reclamation of devasted environment, cost of clean-up and compensation, and other silent non-use or passive cost which may not be easily estimated. Economic impact is interwoven with environmental and social impact which includes pollution of the environment, community conflicts, violence and frustration leading to psychological stress and trauma, and reduction in tourism and hospitality industries. In some societies like the Niger Delta Region of Nigeria, oil spill and activities of the oil companies has extended beyond other global impacts by leading to militancy and youth's restiveness.

Usually, it is difficult to calculate and estimate social cost of spill as such cost includes non-tangible and non- visual cost lost by residents, visitors and other passive users who derive some comfort by looking at the beaches or environment or mere thought of such environment (Garza-Gil et al., 2006; Jones, 2011; Bishop et al., 2017).The residents described the oil spill and pollution of oil producing communities in the Niger Delta Region of Nigeria including Imo State as "drinking water is polluted; fishing and farming are significantly impacted and ecosystems are degraded". "Before oil production started in this area, our water were full of different types of animals, and one did not need to struggle before getting fishes, oil pollution has stopped all that, now, we even have to get fish from other areas, this is unheard of anywhere" (Steiner, 2010, p. 4).

The study utilized the Environmental Kuznets Curve (EKC) theory and stakeholders' theory to explain the oil spill in Ohaji/Egbema and Oguta communities and the Niger Delta region. The pollution in the Niger Delta region has reduced the environmental quality of the region and if income grows by the injection of funds and pollution control policies by the oil companies and government, the level of pollution in these communities would reduce and the sustainable developments would be meaningful. The activities of humans and extraction of natural resources leads to economic expansion and accumulation of waste more than the natural biosphere can accommodate leading to pollution (Luo et al., 2014). In Niger Delta Region of Nigeria, the pollution and economic destructions caused by the oil activities have created much loss of income. Similarly, Wang (2011) using the EKC theory air pollution has acute and chronic effects on humans cause respiratory effects like heart disease, cancer, respiratory infections, premature mortality and reduction in life expectancy. The author explained that the environmental quality due to the activities of humans would deteriorate initially with increase in revenue and improve when income increased to a certain level. Omisakin and Olusegun (2009) study reinvestigates the original concept of EKC by exploring the relationship between environmental degradation and economic growth for a small open developing country, Nigeria with the aim of verifying whether the Environmental Kuznets Curve hypothesis holds in Nigeria and the finding was that shows that there is no causal relationship at all between the variables (CO2 /capita and GDP/capita). Similar study by Akpan and Chuku (2011) shows that EKC hypothesis does not exist in Nigeria. The narrow definition of stakeholders only includes the groups that are vital to the survival and success of the organization, while the wide or broad definition accommodates all groups that can affect or be affected by the actions of the corporation (Freeman \& Reed 1983). The stakeholders in this study includes the farmers and allied businesses, the fishermen, staff of the oil companies, environmental activist, the media, the government and communities living close to the spill area. Stakeholders of a company are not just its direct owners but any person, group or entity that a corporation has benefited or burdened by its actions and those who benefit or burden the firm with their actions (Steiner, 2012; Miles, 2012). Hence the stakeholder's theory goes to explain that all the stakeholders in the oil spill have one thing or the other to share in the spill and the incident of the oil spill affects them (Cleveland, 2010). 


\section{Review of Literature}

Generally, the impact of an oil spill depends on the location, the weather at the time of spill, the size of the spill, the rate of the spill and the type of oil spilled as this impact can last for over a range of time scales, from days to years, or even decades (short time or long time) (Ramseur, 2012). The economic impact of oil spill is quite a broad approach depending on the author's perspective and the estimation of the economic cost proves difficult to evaluate with precision, given the limitations in available baseline data, long-term forecasting methods, and estimation of nonmarket costs (Chang, et al., 2014). Such economic cost is not only on the spilled location, but broadens to other sectors of the economy which makes the actual estimation difficult. Likewise, literature has it that once there is oil spill in a particular location, even the stock market has a share of the impact. Meeuwissen (2012) looked at the economic impact of oil spill especially the BP Deepwater Horizon Gulf spill in relation to the stock market performance after the spill. The study was of the view that after the BP Deep Horizon oil spill, the stock market was affected as well as the company and stakeholders. The sealing of the well after the blowout of $20^{\text {th }}$ April was finally done on 23rd of September, an estimate that 4.4 million barrels of oil were lost in the Gulf during the last three months of leaking, with estimated clean-up costs already neared 10 billion dollars (Meeuwissen, 2012). It was observed that the share price of "BP fluctuated between 655.4 pence on the London Stock Exchange in April to June 29, when the share price was down to 302.9 pence and later appreciated to 425 pence in October" which explains the economic impact of the spill on the company's shares (Meeuwissen, 2012. p. 5). The announcement of BP Deepwater Horizon oil spill on Wallstreet journal led to abnormal return of $2.88 \%$ for BP, Anadarko of $-1.80 \%$, Halliburton $-1.61 \%$, Transocean $-3.38 \%$ and Cameron International $-4.01 \%$ as they were subcontractors. While the US government moratorium announcements led to decline in the share price of both BP plc (-6.04\%) and Anadarko (-7.58\%) (Sabet and Heaney, 2012).

Similarly, some other researchers and evaluators looked at the economic cost based on cost of cleanup, compensation and damages to agricultural land, fishery and wildlife including cost to the environmental pollution and loss of businesses. Pourvakhshouri, (2008), found that the impact of oil spill on the coastal areas including Malaysia which is estimated to be more than 3 million tons per year caused disastrous impacts on the environment, ecology and socio-economic activities. Likewise, Garza-Gil, et al., (2006) analysed the short-term economic impact of the Prestige oil spill of November, 2002 as reports have it that about 40,000 tons of oil leaked into the Sea which covered almost all the coastline in Galicia (Spanish region with a very important coast fishing and tourist activity) and some points in North Spain and in Southwest France. This spill affected the economy of the area as fishing contributed 722,310 Euros (2.23\%) and tourism 1,859,603 Euros (5.73\%) out of total of 32,460,588 Euros of the Galicia gross value added. Also, about 34,000 people employed in the fishing and aquaculture sector, as well as tourism that employed about 51,000 people were affected by the spill, hence leading to lots of economic loss as jobs were lost. The total cost incurred due to the prestige oil spill was enormous and covered all sectors of the economy and environs. The lower bound cost for the year years 2002-2004 was estimated at Euros 770.58 million (prices in 2001 currency). This shows that oil spill cost in very setting can be of high magnitude (Loureiro et al., 2006).

Oil spill contributes to loss of market and health confidence which causes great economic loss not only to the fishing industry but also to the nation (ITPOF, 2014). Niemi, et al., (2001) writing on the socioeconomic effects of oil spill stated as follows: "disrupt local activities and relationships; consume or disrupt local services; degrade or destroy local assets, including physical, financial, and social capital; and increase uncertainty and risk for the local community regarding the environment, human health, economic prospects, and the stability of families, businesses, and organizations". Likewise, Buckingham-Howes, et al., (2019) conducted a study on the prolonged financial distress after the Deepwater Horizon oil spill, and discovered that the victims of the oil spill are still engulfed in the financial stress many years after the spill. This has actually impacted negatively on their living standard and financial comfortability as well as affecting their behavioural health. However, those with property insurance, adequate savings and easier access to loans have lower financial impact as well as less behavioural health impacts.

In a similar study, Psarros, et al., (2011), explained that despite how difficult it is to have exact total cost of oil spill, efforts have been made to categorize oil spill cost into clean-up expenditures and 
compensation payments made. Similarly, Natale, (2010) in a study posits, "estimates that nearly $\$ 1.2$ billion in output and 17,000 jobs will be lost in the Gulf Coast states by the end of the year as a result of the spill. The fishing industry suffered greatly as there were information that The National Oceanic and Atmospheric Administration has closed about 80,000 square miles of the Gulf to fishing, mostly along the Louisiana coastline. Though the closure extends as Far East as Panama City and Louisiana beach has been closed to swimmers and fishermen, and several Alabama and Florida Panhandle beaches are advising swimmers of the presence of tar balls and oil sheens, though the beaches remain open in Florida (Natale, 2010). Hence, one does not need a soothsayer to tell that there would be loss of jobs and income on the part of the tour organizers and others that have economic activities operating around the beaches. Hardest hits are Louisiana, with its heavy dependence on fishing, aquaculture and oil extraction, and Florida, with its tourist industry. The metro areas and counties that line the shores of the Gulf are already bearing the brunt. The economic cost of the Deepwater Horizon spill was evaluated and it affected many sectors and residents of Louisiana, however the compensation paid to the people and businesses was an advantage to boost their lives and businesses as it could be seen as economic injection. There was a short time increase in income and employment especially hotel related industries as many journalist and visitors went to the area as a result of the spill, however the impact of oil spill affects the oil and gas industries, the fisheries and tourism and related businesses (Taleghani and Tyagi, 2017). The Deepwater Horizon spill cost BP a whole big sum of money, on June 16, 2010, BP agreed to set aside $\$ 20$ billion into an escrow account so as to take care of losses incurred in income and property damages due to the oil spill, and also on July 2015 agreed to pay $\$ 18.7$ billion to settle remaining state and federal claims with other additional cost pushing the total cost to about $\$ 54$ billion (Humphrey, Carter \& Simkins, 2016). The oil spill caused economic hardship to the fishermen and communities who have their livelihood linked to the spill. The crabs, the oysters and other sea animals died, and people were afraid to eat even the harvested ones for fear of contamination and health impacts. These conditions affected sales greatly and hence the income was very low (Cherry et al., 2015). There were loss of jobs and economic activities after the BP Deepwater Horizon oil spill. In a related study, the Deepwater Horizon oil spill have greatly affected the environment and the fishing and allied industries and the most hit were the lucrative shrimp, blue crab, menhaden, and oyster fisheries causing a minimum loss in annual landed value of US\$247 million (McCrea-Strub et al., 2011). Ritchie et al., (2013) evaluated the effects of the Gulf oil spill on tourism and the related sectors which they found to have seriously created negative impact resulting to an estimated business owners out of court settlement cost of US $\$ 13.5$ billions paid by BP Company. Likewise, BP oil spill estimated total cost to the environment, and the US gulf coast economy was $\$ 36.9$ billion (Smith, Smith and Ashcroft 2010).

In a study, Ramseur (2012), explained that the economic cost of spills involves looking at the losses experienced by those who depended on business resources and reputation of the local environment as the spill disrupted their business activities. Besides that, the local fishing and tourist industry may be affected, local infrastructure and services can be disrupted, port and harbour operations may be interrupted, altering the flow of traded goods and services, and other industries close to the spill area may be adversely affected. The economic clean-up costing from oil spill could be categorized into "clean-up expenses, natural resource damages, and the various economic losses incurred by the affected community or individuals". it should be noted that the clean-up cost is determined by the location of spill, the type of spill and the volume of spill (Ramseur, 2012, p. 7). Gill \& Picou, (2001), discussed the economic and social impact of the Exxon Valdez oil spill as the Alaskan communities' intimate relationship with their environment and ecosystem were disrupted along with their cultural norms, subsistence, cultural tradition and psychosocial well-beings were adversely affected. many of the fishing boats were just by the sea side for months without use, many strangers were in the communities especially journalist and response workers and these affected the natives who have not been used to such foreigners. similarly, loss of economic activities in the gulf spill was imagined when it was stated that "fishing in the gulf of Mexico is an estimated \$2.4 billion industry and nineteen percent (19\%) of the gulf coast, or 46,000 square miles, is currently closed to fishing, between the Mississippi river and the Pensacola bay (Betinis, 2010). Hotels in Mississippi were reported to have experienced losses as much as $50 \%$ during the period, while those in Alabama were reporting losses of between 100,000 and 200,000 within two weeks of the spill. On the other hand, reports had it that hotels in Louisiana were having boots due to journalist, nearly 25,000 scientists, 
environmentalists, clean-up workers, photographers and other lodgers staying there to cover the gulf spill (Betinis, 2010). Similarly, there is a linkage between economic loss and stress with the communities and culture which the Deepwater Horizon oil spill affected (Hobfoll, 2012). Resource loss and gains are not proportionate as the loss is more salient than the gain and resource loss is associated with distress, and comprehensive multilevel impact. this is connected to caravan passageways. such "caravan passageways are the environmental conditions that support, foster, enrich, and protect the resources of individuals, families, and organizations, or that detract, undermine, obstruct, or impoverish people's resource reservoirs" (Hobfoll, 2012, p. 229).

Likewise, Jones (2011) stated that one year after the Gulf oil spill, rental reservations were still down by over $25 \%$ in the gulf region and tourism decreased significantly as most tourist were sceptical about the hygienic condition of the water despite the clean-up. Social cost of oil spill takes a greater approach and coverage in events of spill and usually most compensated cost approved by the International Oil pollution compensation involves private cost once they could be calculated and proved. Such private costs are those related to the fisheries and seafood sectors, tourism on coastal areas and destruction of farm lands and other economic activities including buildings in case of spills in residential areas. The social cost in most cases is not quantifiable. The social cost in the event of oil spill includes cost of the loss of recreation opportunities for residents (use of beaches, landscape, etc.) and passive use losses which are more psychological in nature and not easily and tangibly quantified and these are grouped as "biodiversity cost" (cultural, existence and heritage values) (Garza-Gil et al., 2006).

Similarly, the Hebei Spirit oil spill in 2007 in Korea caused severe harm to fisheries as the spill covered $375 \mathrm{~km}$ of coastline of Chung Cheong affecting about 43,000 fishing household. (Pan, et al., 2015). The oil spill that occurred at Penglai Yantai fisheries in Bohai Sea of northeast China led to loss of "CNY1239.35million" which comprised of "mariculture loss of CNY1239.50 million and other related stocking fisheries program loss of CNY16.85million" (Pan et al., 2015, p. 22). Also, in July 2010, there was an oil spill in Dalian China that polluted $430 \mathrm{~km}$ square of coastline and about 1500 tons of oil were spilled with a total estimated spill cost of CYN4480 million including clean-up. The estimated total economic loss of mariculture due to the oil spill was valued at 2011 market price to be CNY1239.50 Million, while the direct economic losses in terms of sales of Chinese white shrimp (Penaeus chinensis), gazami crab (Portunus trituberculatus) and flame jellyfish (Rhopilema esculentum) amounted to CNY16.85 Million. This transcended to overall estimated loss of CNY1256.35 Million (mariculture and juvenile stocking programme) as at 2011 excluding other economic losses and tourism (Pan et al., 2015 p.21-22). In 1996 oil spill caused by the Sea Empress polluted the coast of U.K with about 72,360 tonnes of oil which led to total economic loss of US\$ 63.147 million, while Erika oil spill of 1999 in France caused about US\$549.1 million ecological damage and US\$234.3 million material damage.

Amoco Cadiz oil spill of 1978 released 230,000 tons of oil and afflicted $300 \mathrm{~km}$ of the French coast, estimated to have destroyed 6400 tons of oysters, leading to an estimated loss of 26 million francs, while the tourism industry suffered a decline of $11 \%$, resulting in a loss of 240 million francs (Cheong, 2012). Exxon Valdez spilled approximately 38,800 tons and polluted large area of the coast totaling $1,900 \mathrm{~km}$ and the estimated loss to fisheries was US\$287 million, sports and recreational fisheries worth US\$580 million and the tourism industry lost US\$5.5 million, while the overall economic loss to the residents was about US\$870 million. Prestige oil spill occurred 30 miles west of Galicia, spilling 77,000 tons leading to a loss of sales income of EUR 1.39 billion in the fisheries sector in 2003 with an overall loss of 4 billion EUR in the fishery industries and EUR 210.4 million losses in tourism-related income (Cheong, 2012). All these shows the great economic losses all over oil spill locations.

Economic values can be computed using the used (active) which are the satisfactions individuals derive from using a resource like the beach or fishing and the non-used (passive) values arises as the individual just derive satisfaction by just thinking of the resource even though not used or visit the resource of the location (Bishop et al., 2017). The place of economic impact of spill could be positive or negative depending on the circumstances and consideration of short term or long term. However, the compensation to the communities affected by the Hebei-Spirit oil spill of December 7, 2007 manifested an economic boom to the communities through the compensations paid at the short term impact though the long-term impact created more negative consequences (Cheong, 2011). Fishing and 
tourism activities declined greatly as fish catch fell from $7789 \mathrm{~m} / \mathrm{t}$ in 2007 to $789 \mathrm{~m} / \mathrm{t}$ between January and March of 2008 resulting to a major decline in the economic activities of these communities who are mainly fish farmers. The tourism industry suffered a great setback as about 32 beaches in Taean hosting 1,164 small-scale accommodations including small inns, home stays, motels, and a youth hostel were deserted and the tourists declined to 876,344 between January and May of 2008 compared to the same period in 2007, which recorded a tourist receipt of 1,907,892 had consequences on the economy (Cheong, 2011). Fish processing and related industries were closed and the export of fishes reduced drastically and importers shunned fishes from other uncontaminated sites and South Korea generally for fear of the contamination and this caused great economic loss to the country. Hotels were affected especially the homestays as visitors had to cancel their bookings for fear of contaminations through consumption of oiled foods and this caused great economic loss (Cheong, 2012).

\section{Economic Impact of the oil spill in Imo State Nigeria}

Oil production in Nigeria is contributing greatly to Royal Dutch Shell's total profit, as at $2005-2009$ annual average of US $\$ 1.8$ billion profit representing $7.3 \%$ out of Shell's $10.4 \%$ profit from upstream operations came from Nigeria (Kate, 2011, p.6). This makes Nigeria the most important country for Royal Dutch Shell. During the period of 2006 - 2010, 16\% of Shell's worldwide oil and liquid natural gas was produced in Nigeria as Shell has "86 oil fields, 1,000 producing wells, 68 flow stations, 10 gas plants and two major oil export terminals at Bonny and Forcados" with about 150 to 200 oil spills yearly in the Niger Delta region (Kate, 2011, p.6). According to the Department of Petroleum Resources annual report, (1997), over 6,000 spills had been recorded in the 40 years of oil exploitation in Nigeria, with an average of 150 spills per annum. In the period $1976-1996,647$ incidents occurred resulting in the spillage of 2,369,407.04 barrels of crude oil. With only 549,060.38 barrels recovered, $1,820,410.50$ barrels of oil were lost to the ecosystem. Oil spill is a regular occurrence in the Niger Delta Region of Nigeria recording about ten times a week and these spills are traceable to oil installations (pipelines, flowlines, well-heads, flow stations, storage tanks etc.), while National Oil Spill Detection and Response Agency (NOSDRA), explained that oil companies reported 2,054 cases of oil spill incidents (spills of more than one barrel) between June 2006 and June 2010 (Amnesty International \& Friends of the Earth 2011, p. 4).

The oil spill in the Niger Delta region of Nigeria is estimated at over 2,567,966 barrels in 5733 incidents in the Niger Delta from 1976-2000 in which about 549,060 barrels were recovered while $1,820,411$ barrels were lost to the environment. The cumulative spilt volume within the period is nearly 10 times more than the total quantity that was spilled in the Exxon Valdez disaster (Ite et al., 2013). These details explain the magnitude of oil spill in Nigeria and the resultant economic damages and pollution that follows as well as increasing the poverty of the oil communities.

In a study conducted by Inoni et al., (2006), it was discovered that oil spill affected crop yield and land productivity in Delta state of Nigeria by $1.3 \%$ which led to $5 \%$ reduction in farm income as 50 percent of the active labour force is engaged in agricultural activity, with yam, cassava, plantain, maize, cocoyam and vegetables as the predominant food crops in the area. This has led to increased poverty and diversification into other economic activities just to make a living. The greatest recent social problem the spillage and activities of the oil company have caused in the Niger Delta is the militarization of the region which have seriously affected the economic status of the communities (Sofiri, 2007; Francis et al., 2011; Adetunberu, 2019; Adisa, 2018; Phenson et al., 2014; Isidiho \& Sabran, 2015a, 2015b).

\section{Compensation After the Oil Spill}

Compensation has been a task and controversial issue when oil spill occurs and there is this problem of stress, anxiety, conflicts and ultimately social disintegration when communities are faced with issues of compensation and modalities of assessing and payment of the compensation funds (Picou et al., 2004). For tanker spill compensations, the liability rest on the shipowners to a certain amount depending on the capacity of the ship and the International Oil Pollution Compensation Fund (IOPC) which draws some funds from all shipowners in case of such liabilities (Cheong, 2011). According to 
the Civil Liability Convention (CLC) 1992, ship oil spill pollution damage is defined as "loss or damage caused outside the ship by contamination resulting from the escape or discharge of oil from the ship". The compensation cost for the environmental damage was such restricted to only cost of reasonable measures for the reinstatement of the environment incurred or to be incurred in monetary loss (Kim et al., 2014, p. 533). In most cases, the estimation of this environmental replacement cost is arguable especially in rural areas where there is no documentation of farming and fishing businesses like in the Hebei spirit oil spill in Korea and such problem exist in Imo state Nigeria as the spill occurs in rural communities. The financial compensation for oil spill damages under the cleanup operation, economic losses and damages to property were covered under the supplementary funds outside the 1992 and 1971 convention by Civil Liability and the International funds for compensation respectively (Kim et al., 2014), however, most countries like Spain in the case of Prestige oil spill, United States in the case of Exxon Valdez oil spill and Deepwater Horizon spill, Erika oil spill in France, and Hebei Spirit oil spill in South Korea apply their own country or regional oil spill laws to secure reasonable compensation from the oil companies or ship owners.

Compensations in Imo State oil spill are all on land and fishing water as a result of either operational errors, malfunctioning of the valves, corrosion or vandalization. The issue of spills from oil tankers does not arise as it is a local community with oil drilling facilities, the liability lies on the oil companies whose activities caused the spill and partly on the Nigerian Government since the oil companies pays royalty and taxes to the government. However, the parameters for assessing the compensation have posed great problems when oil spill occurs in these communities. In other locations of tanker spill like South Korea, the assessment for fishing is based on the number of fishing boats while for businesses around the beaches and spill coastlines, consideration is made based on income or turn over recorded by the individuals or groups monthly and tax payable (Cheong, 2012). For rural communities like Imo State, the valuation of the compensation based on the farmland size polluted, the crops and economic activities on the farm, the environmental hazards and the general socioeconomic damages caused by the spill becomes cumbersome to calculate. There are no records on the total weekly or monthly income accruable to the farmers or fishermen, taxes are not accurately assessed based on income as no accurate statistics. Most times the taxes were levied as flat rate on every adult male within the taxable range in the communities, hence the issue of adequate compensation becomes arguable by both the oil companies and the communities.

The assessment of the economic impact of oil spill in the study is using the data collected from the field by the researcher as there have not been any recorded data on the income per head or household of the community members. As a rural developing community, there are no data on income per head of the farmers before and after the oil spill. Most of the residents interviewed were not able to give exact income they generated from their farms and fishing as they do not keep the records rather, they knew they were getting little or less income after spills as they could have little or no farm products and fishes to sale and make money. This makes the assessment different from other locations. Similarly, the economic or financial loss of the residents in the Gulf and Exxon Valdez spill were estimated based on previous data on their income. In other locations of spill, the calculation of social cost and part of the psychological cost are relative based on the culture and the verse knowledge of the assessor. What may be attached as social cost in one community in Europe, America or Asia may not be attached as social cost in Africa as the culture and societal views and assessment varies. Like the interest of visitors and inhabitants in the ecstasy of the terrain of the coastlines and amazons before the Gulf oil spill was of great value to them while such views very irrelevant in Ohaji/Egbema and Oguta communities in Imo state as it is absolutely a rural farming community without visitors and no commercial photographer to take and market images of these farmlands and fishing waters.

\section{METHODOLOGY}

The study was conducted in Ohaji/Egbema and Oguta communities in Imo state Nigeria as there is frequent oil spill in these communities who are mainly farmers and fishermen. Ohaji/Egbema Local government area has a population of 182,538, while Oguta Local government Area has a population of 143,008 (National Population Commission of Nigeria Census, 2006). The peculiar characteristics of the oil spill in these locations is its occurrence both on land and water which pollutes the water 
making it unsafe for community use while the fishes and aquatics are destroyed and spill on the land destroys the farmlands and crops. Mixed method approach was used in data collection; meaning questionnaires were administered, and interviews were conducted (Tashakkori \& Teddlie, 1998, Teddlie \& Tashakkori, 2009, Creswell, 2009, Creswell \& Plano Clark 2007, p. 5). A total of 376 respondents from the questionnaires administered and 13 informants were interviewed. Respondents in this study were chosen conveniently from the population as the inclusion criteria was residency in Ohaji/Egbema and Oguta within the ages of 18 through 86 and above. The data on the income before and after the oil spill was analysed using descriptive statistics. The use of the unstructured interview style helped the informants to open up freely in releasing adequate data having reasonable experience, knowledge and willingness to give accurate information on the impact of the oil spill in their communities. The qualitative data was analysed using coding and thematization.

\section{FINDINGS}

Some resident farmers and fishermen were also selected to be interviewed to get informant's data on the economic impact of the spill on them and their community. Informants during the interviews said:

"When the water is covered by oil and fishermen can no longer find fishes, when the farmlands and crops planted are soaked by oil and the crops die or look pale, brown or yellow leading to non or very poor yields, and when the mangroves and other cash crops and economic trees are destroyed and they dry up, how can families raise money to train their children? Even local palm wine and raffia wine tappers can no longer operate as the crude oil soaked these palms and they dry and die off. They don't have enough raffia palms to tap again and that reduced their supply of palm wine to the community and markets".

"The air we breathe are crude oil, the land we step on is crude, the water we drink, use to wash, cook and do other house activities are mixed with oil. Everything here smells and taste oil. So, our life in these communities are covered with crude oil, very difficult to live life like this, if care is not taken, we would all turn to oil ourselves"

"Since these oil spill, our family income has reduced and many families most hit as we cannot farm and fish. Our farmlands were affected by the previous spills and it takes years for the vegetation to recover. Even when they recover, the yields are very poor and annoying. It is only this trade that is helping me but the profit from the trading is not big. Many people and families here in our community are living only by grace of God. To eat and change clothes are very difficult. The oil spill and the general economic collapse in the country with the very high level of corruption is affecting us seriously".

Another informant tried to explain the psychological trauma prevalent in their community and occupational change as a result of the financial loss and reduced income due to the spill. He stated;

"There are lots of psychological stress which impacted negatively on the people. Some who lost their farms started grumbling, murmuring, colloquizing and the anxiety are much and visible. There is always complains and fears of the unknown and the future, having lost their means of income, the communities are seen as confused, embarrassed by the spill and the unfriendly, intimidation, harassment and other activities of government security agencies creates psychological trauma among our people and communities daily. Such psychiatric symptoms could be noticed when you talk with people and the level of aggressiveness was very high leading to fights and harms".

"I have said it that our income has been very low as oil damaged our sources of income. This community is a traditional farming society and our major sources of income are the land and waters. Very few used to be traders but with the damages to land and waters, many have started trading with small capital they have while some bought tricycle on 
hire purchase and started rural transportation business. They cannot fold their hands and stay idle. Our income is seriously affected".

The data from respondents on their average level of income before and after the spill showed a great disparity as the income decreased drastically after the spill. Table 1 and 2 below show these differences. While the highest $(36 \%)$ of the respondents were making average of Fourteen thousand Naira $(\mathrm{N} 14,000.00)$ per week before the spill, the highest average income after the spill was Five thousand Naira $(\mathrm{N} 5,000.00)$ per week as $(35 \%)$ of the respondents commented. Similarly, $(24 \%)$ of the respondents were making average income of above Fifteen thousand Naira (N15, 000.00) per week before the spill while, only $(5 \%)$ of the respondents were making average of same Fifteen thousand Naira (N15, 000.00) after the spill. This explains the negative effect of the oil spill on the income of the communities. This loss and reduction of income due to the oil spill resulted in serious economic, social and occupational crisis and this is supported by previous studies that concluded that oil spill reduces income of residents and business owners around the spill (Inoni et al., 2006; Niemi et al., 2001; Garza-gil et al., 2006; Betinis, 2010; Pan et al., 2015; ITPOF, 2014; Gill \& Picou, 2001; Ramseur, 2012). Literature has it that unanticipated financial resource loss, income loss or unemployment and non-palliative measures leads to physical and mental stress after oil spill (Grattan et al., 2017).

Table 1: Average Income per week before the oil spill (Nigerian Naira)

\begin{tabular}{|c|c|}
\hline Nigerian Naira (N) & Frequency of income earners (\%) \\
\hline $\mathrm{N} 2,000$ & 1.7 \\
\hline $\mathrm{N} 5,000$ & 8.2 \\
\hline $\mathrm{N} 8,000$ & 12.5 \\
\hline $\mathrm{N} 11,000$ & 17.3 \\
\hline $\mathrm{N} 14,000$ & 36.4 \\
\hline Above N15,000 & 23.9 \\
\hline
\end{tabular}

Source: Author's compilation from the questionnaire

Table 2: Average Income per week after the oil spill (Nigerian Naira)

\begin{tabular}{|c|c|}
\hline Nigerian Naira $(\mathrm{N})$ & Frequency of income earners $(\%)$ \\
\hline $\mathrm{N} 2,000.00$ & 11.0 \\
\hline $\mathrm{N} 5,000.00$ & 34.8 \\
\hline $\mathrm{N} 8,000.00$ & 31.4 \\
\hline $\mathrm{N} 11,000.00$ & 13.6 \\
\hline $\mathrm{N} 14,000.00$ & 4.3 \\
\hline
\end{tabular}




\begin{tabular}{|c|c|}
\hline Above N15,000.00 & 4.9 \\
\hline
\end{tabular}

Source: Author's compilation from the questionnaire

The loss and decrease in income led to serious economic and social effects such as conflicts between the local communities, oil companies and government as witnessed in Imo State, the Niger Delta Region and many locations of oil spill including Hebei spirit oil spill, the Gulf of Mexico oil spill, and the Exxon Valdez spill. While the conflict in South Korea spill was due to blames on the slow cleanup exercise, compensation processes, and disagreements between the tourist and the fishing groups (Cheong, 2011).

Similarly, conflict was observed during the Gulf oil spill as Watkins (2010) described it as "a classic failure of system leadership" " precisely why a different procedure was used is the subject of the finger-pointing, Halliburton says it was told to do so by Transocean, Transocean alleges that it was so instructed by BP. Regardless, it appears that a very bad decision was made for which no one is willing to take responsibility" In this case the conflict that emanated from the cause of the spill initially was between the major players in the oil drilling. However, the resultant conflict between the individuals and business communities whose activities were affected on one hand and the oil companies and government on the other hand as the people complained of the destruction of their environment and slowness in remediation.

The conflict in Imo state was on the non-cleanup exercise, non-compensation, non-provision of basic social amenities and the consequences of the spill which led to open confrontation, shooting and killings between the youths and the military, which later metamorphosed into kidnapping and hostage taking of oil workers and demanding of ransom before they were released, destruction of oil installations and high levels of breakdown of law and order in the oil region (Alumuna, et al., 2017). However, despite the negative economic and social impacts of the spill, some positive impacts were recorded in the oil communities in Imo State and Niger Delta Region of Nigeria such as new skills acquisitions and occupations, new sources of income that had been previously neglected like people started construction of fish ponds in their compounds and surroundings, oil palm plantations started springing up as alternatives to farming, commercial poultry and piggery, alternative developments and digging of private boreholes and commercialization of the borehole water, new disaster control and resuscitation policies. Such resilience from the residents is highly commendable and sustainable as studies have it that without such alternatives, the economic, environmental and financial stress combined can lead to serious psychological and behavioural problems such as post-traumatic stress disorder, anxiety, and depression (Grattan et al., 2011; Mong et al., 2012, Palinkas, 2012, Goldstein et al., 2011; Grattan et al., 2017). Such self-efficacy, mastery, faith, hardiness, persistence, determination to survive and succeed to come out with better behavioural outcome despite the negative impact of the oil spill is highly exhibited by the residents of Ohaji/Egbema and Oguta in Imo states and the Niger Delta in general and this agrees with the findings of Osofsky et al., (2012) and Grattan et al., (2017).

\section{DISCUSSION}

The issue of oil spill effect on income and the economy is a global issue and expands beyond the oil spill location or community as it has a multiplier effect. Literature has it that the oil spill has negative impacts on the income of people and businesses around oil spill and same in Ohaji/Egbema and Oguta communities in Imo State Nigeria. However, findings have shown that the payment of compensation have helped to cushion the impacts despite the fact that recipients have continued to complain of the inappropriateness of the compensation to put them, their businesses and environment back to the exact level they were before the spill. The unfortunate thing about the spill in Imo State and the Niger Delta Region is that residents have claimed there was little or no compensation and whenever such is paid it was very little and rather called just a "financial tip".

The international legislation has been reported by researchers as not comprehensive enough to ensure adequate compensation; hence various countries and regions have invoked and applied their local spill 
legislations in events of oil spill so as to secure reasonably enough financial claims as adequate compensation. Unfortunately, the findings in Imo State shows that despite the membership of Nigeria to the international oil spill conventions and also the promulgation of local oil spill laws, the laxity, and political will to enforce these laws strictly has not been there hence, oil companies find excuses and loopholes not to pay compensations to the affected individuals and communities. Findings also showed it that people of the oil spill locations in Imo State who are predominantly crop farmers and fishermen have lost their means of income. They do not have enough capital to venture into alternative lawful economic activities for survival. The spill has negatively affected their economic and social life, increasing poverty, disease, communal conflict and other social ills. However, the spill has forced them to diversify and exploited other revenue generation activities that have been neglected such as building and operating private commercial fish pounds, transportation businesses, oil palm plantations and host of others as occupational displacement from traditional crop and fish farming.

The study therefore concludes that the economic impact of oil spill is damaging to people having their means of livelihood on waters, along the coastlines, and farmlands and should be given adequate and urgent considerations in events of spill. Similarly, international oil spill laws need to be revisited to make comprehensive provisions to ensure adequate compensations for oil spill both from ship and on land. All the necessary agencies should be active and strict in the implementations of the oil spill laws existing in the country, while the court system should be devoid of laxity, malpractices and ensure speedy dispensation of oil spill cases. The oil companies operating in Imo State and the Niger Delta region and the Nigerian government should be proactive in events of spill and ensure urgent clean-up so as to reduce the impacts and at the same time commence effective evaluation and assessment of the impact and compensation to the affected. Furthermore, a remediation program should be initiated and financed both by the oil companies and the Federal government of Nigeria to caution the effects of economic loss to the communities through provision of soft loans to the communities affected by the oil spill for occupational diversification.

\section{REFERENCES}

Adetunberu, Oludotun (2019). Oil Conflicts and Arms Proliferation in Ogoni and Ijaw Region of Niger Delta, Nigeria: The Possible Solutions. American Journal of Humanities and Social Sciences Research (AJHSSR), 3, 121-129.

Adisa, Oluyemi Opeoluwa (2018). Implications of Using the Military and Para-military Forces for Securitizing Nigerian Insecurities: The Case of Niger Delta Crisis. American International Journal of Social Science, 7, $46-57$.

Akpan, Usenobong F. and Chuku, Agbai (2011). Economic Growth and Environmental Degradation in Nigeria: Beyond the Environmental Kuznets Curve. Paper Presented at the 4th Annual NAEE/IAEE International Conference, held at Sheraton Hotels and Towers, Abuja, Nigeria, April 27th $-29^{\text {th }}$, pp. 129. Online at https://mpra.ub.uni-muenchen.de/31241/ MPRA Paper No. 31241.

Alumuna, S., Ofoegbu, R. C., \& Edet, A. S. (2017). Militancy and Kidnapping in the Niger Delta Region of Nigeria: A Recap. Elixir Social Studies 112, 49425 - 49434.

Amnesty International Report and Friends of the Earth International (2011). UNEP Findings on Complaint: Complaint to the UK and Dutch National Contact Points under the Specific Instance Procedure of the OECD Guidelines for Multinational Enterprises 30 December. https://www.business-humanrights.org/sites/default/files/media/documents/ai-foe-oecd-complaint-reshell-30-dec-2011.pdf.

Betinis, Kristina (2010). The social and economic impact of the Gulf oil spill. World Socialist Web site: (Accessed online10/02/2020). https://www.wsws.org/en/articles/2010/05/gulf-m24.html. 
Bishop, R. C., Boyle, K. J., Carson, R. T., Chapman, D., Hanemann, W. M., Kanninen, B., ... Scherer, N. (2017). Putting a value on injuries to natural assets: The BP oil spill. Science, 356(6335), 253-254. doi: https://10.1126/science.aam8124.

Buckingham-Howes, S., Holmes, K., Glenn Morris, J., \& Grattan, L. M. (2019). Prolonged Financial Distress After the Deepwater Horizon Oil Spill Predicts Behavioral Health. Journal of Behavioral Health Services and Research, 46, 294-305.

Chang, S., Stone, J., Demes, K., \& Piscitelli, M. (2014). Consequences of oil spills: A review and framework for informing planning. Ecology and Society, 19(2) 26. Retrieved April 15, 2020, from https://www.jstor.org/stable/26269587

Cheong, S.-M. (2011). A social assessment of the Hebei-Spirit oil spill. GeoJournal, 76, 539-549. doi: https://10.1007/s10708-010-9368-4.

Cheong, S.-M. (2012). Fishing and Tourism Impacts in the Aftermath of the Hebei-Spirit Oil Spill. Journal of Coastal Research, 285, 1648-1653. doi: https://10.2112/jcoastres-d-11-00079.1

Cherry, K. E., Lyon, B. A., Marks, L. D., Nezat, P. F., Adamek, R., Walsh, S. D., ... Bernacchio, C. V. (2015). After the BP Deepwater Horizon Oil Spill: Financial and Health Concerns Among Coastal Residents and Commercial Fishers. Current Psychology, 34, 576-586. doi: http://10.1007/s12144-015-9372-4

Cleveland, C. J. (2010). Deepwater Horizon Oil Spill. Retrieved from Encyclopaedia of Earth: http://www.eoearth.org/article/Deepwater_Horizon_oil_spill?topic=50364

Creswell, J. W. (2009). Research design: Qualitative, quantitative and mixed methods approach (3rd ed.). London: Sage.

Creswell, J. W., \& Plano Clark, V. L. (2007). Designing and Conducting Mixed Methods Research. London: Sage Publications Ltd.

Francis, Paul, Deirdre Lapin, \& Paula Rossiasco (2011). Securing Development and Peace in the Niger Delta. A Social and Conflict Analysis for Change. Study prepared for publication by the Woodrow Wilson International Center for Scholars Africa Program and Project on Leadership and Building State Capacity. Woodrow Wilson International Center for Scholars Africa Program. https://www.wilsoncenter.org/sites/default/files/AFR_110929_Niger\%20Delta_0113.pdf

Freeman, R. E., \& Reed, D. L. (1983). Stockholders and stakeholders: A new perspective on corporate governance. California Management Review, 25(3), 88-106.

García Negro, M. C., Villasante, S., Carballo Penela, A., \& Rodríguez Rodríguez, G. (2009). Estimating the economic impact of the Prestige oil spill on the Death Coast (NW Spain) fisheries. Marine Policy, $33(1), 8-23$. doi: https://10.1016/j.marpol.2008.03.011

Garza-Gil, M. D., Prada-Blanco, A., \& Vazquez- Rodriguez, M. X. (2006). Estimating the short-term economic damages from the Prestige oil spill in the Galician fisheries and tourism. Ecological Economics, 58 (4), 842-849.

Gill, Duane A. \& J. Steven Picou. (2001). The Day the Water Died. New York Press. New York and London.

Gill, D. A., Ritchie, L. A., \& Picou, J. S. (2016). Sociocultural and psychosocial impacts of the exxon valdez oil spill: Twenty-four years of research in Cordova, Alaska. The Extractive Industries and Society, 3(4), $1105-1116$. doi: https://10.1016/j.exis.2016.09.004 
Goldstein, B.D., Osofsky, J.H. \& Lichtveld, M.Y. (2011). The Gulf oil spill, New England Journal of Medicine, 36(14), 1334-1348.

Grattan, Lynn M., Babette Brumback, Sparkle M. Roberts, Stacy Buckingham-Howes, Alexandra C. Toben, \& Glenn Morris (2017). "Bouncing back" after the Deepwater Horizon oil spill, Disaster Prevention and Management: An International Journal, 26(2), 122 - 133.

Grattan, L.M., Roberts, S., Mahan, W., McLaughlin, P.K., Otwell, W.S. and Morris, J.G. Jr (2011). The early psychological impacts of the Deepwater Horizon oil spill on Florida and Alabama communities, Environmental Health Perspectives, 119(6), 838-843.

Hobfoll, Stevan E. (2012). Conservation of resources and disaster in cultural context: the caravans and passageways for resources. Psychiatry: Interpersonal and Biological Processes, 75(3), 227-232. https://doi.org/10.1521/psyc.2012.75.3.227

Humphrey, P., Carter, D. A., \& Simkins, B. (2016). The market's reaction to unexpected, catastrophic events. The Journal of Risk Finance, 17(1), 2-25. doi: https://10.1108/jrf-08-2015-0072

Inoni, O. E., Omotor, D. G. \& Adun, F. N. (2006). The effect of oil spillage on crop yield and farm income in Delta State, Nigeria. Journal of Central European Agriculture, 7(1), 41-48.

Isidiho, O. A., \& Mohammad S. Sabran (2015a). Challenges Facing Niger Delta Development Commission (NDDC) Projects in Imo State and Niger Delta Region in Nigeria. International Journal of Humanities and Social Science, 5(6), $37-48$.

Isidiho, O. A., \& Mohammad S. Sabran (2015b). Socio-Economic Impact of Niger Delta Development Commission (NDDC) Infrastructural Projects in Selected Communities in Imo State Nigeria. Asian Journal of Humanities and Social Sciences (AJHSS), 3(2), 109 - 113.

Ite, E. A. J., Ibok, U. U., Ite, M. \& Petters, W. S. (2013). Petroleum Exploration and Production: Past and Present Environmental Issues in the Nigeria's Niger Delta. American Journal of Environmental Protection, 1(4), 78-90.

Jones, C. (2011). Tourism returning a year after the Gulf oil spill. Retrieved from USA Today: http://usatoday30.usatoday.com/news/nation/2011-04-20-tourism-rebounds-gulf-.htm

Kate, A. (2011). Royal Dutch Shell and its sustainability troubles. Background report to the Erratum of Shell's Annual Report 2010, May, $1-71$.

Kim, D., Yang, G., Min, S., \& Koh, C. (2014). Social and ecological impacts of the Hebei Spirit oil spill on the west coast of Korea: Implications for compensation and recovery. Ocean \& Coastal Management, 102, 533-544. doi: https://10.1016/j.ocecoaman.2014.05.023

Luo Y, Chen H, Zhu Q, Peng C, Yang G, Yang Y, et al. (2014). Relationship between Air Pollutants and Economic Development of the Provincial Capital Cities in China during the Past Decade. PLoS ONE 9(8): e104013. https://10.1371/journal.pone.0104013

Loureiro, M. L., Ribas, A., López, E., \& Ojea, E. (2006). Estimated costs and admissible claims linked to the Prestige oil spill. Ecological Economics, 59(1), 48-63. doi: https://10.1016/j.ecolecon.2005.10.001

McCrea-Strub, A., Kleisner, K., Sumaila, U. R., Swartz, W., Watson, R., Zeller, D., \& Pauly, D. (2011). Potential Impact of the Deepwater Horizon Oil Spill on Commercial Fisheries in the Gulf of Mexico. Fisheries, 36(7), 332-336. doi: https://10.1080/03632415.2011.589334 
Meeuwissen, (2012). The BP-oil spill, a crisis for BP or for the whole industry? Master Thesis Department of finance, School of Economics and Management, Universiteit Van Tilburg. (Accessed online on 24/04/2020) http://arno.uvt.nl/show.cgi?fid=127159

Mong, M.D., Noguchi, K. and Ladner, B. (2012). "Immediate psychological impact of the Deepwater Horizon oil spill: symptoms of PTSD and coping skills", Journal of Aggression, Maltreatment, and Trauma, Vol. 21 No. 6, pp. 691-704.

Miles, Samantha (2012). Stakeholders: essentially contested or just confused? Journal of Business Ethics 108(3), 285-298.

Natale, Marisa Di (2010). The Economic Impact of the Gulf Oil Spill. Moody's Analytics. (Accessed online on 24/ 04/ 2020) https://www.economy.com/economicview/analysis/191641/The-Economic-Impact-of-the-Gulf-Oil$\underline{\text { Spill }}$

Niemi, R. \& Heiskanen, Ilse \& Wallenius, Kaisa \& Lindström, Kristina. (2001). Extraction and purification of DNA in rhizosphere soil samples for PCR-DGGE analysis of bacterial consortia. J. Microbiology Methods, 45, 155-165.

Okonkwo, Eloamaka Carol (2014). Oil Spills in Nigeria: Are there Social and Economic Impacts? International Oil Spill Conference Proceedings: May, Vol. 2014, No. 1, pp. 300289. https://doi.org/10.7901/2169-3358-2014-1-300289.1

Omisakin, D. and A. Olusegun (2009). Economic growth and environmental quality in Nigeria: does environmental Kuznets curve hypothesis hold? Environ. Res. J., 3 (1) (2009), pp. 14-18.

Osofsky, H.J., Osofsky, J.D. and Hansel, T.C. (2012). Commentary on “A conceptual framework for understanding the mental health impacts of oil spills: lessons from the Exxon Valdez oil spill'- mental health perspectives following the Gulf oil spill, Psychiatry, 75(3), 233-235.

Osofsky, J. D., Osofsky, H. J., Weems, C. F., Hansel, T. C., \& King, L. S. (2014). Effects of Stress Related to the Gulf Oil Spill on Child and Adolescent Mental Health. Journal of Pediatric Psychology, 41(1), 6572. doi: https://10.1093/jpepsy/jsu085

Palinkas, L.A. (2012). A conceptual framework for understanding the mental health impacts of oil spills: lessons from the Exxon Valdez oil spill, Psychiatry, 75(3), 203-222.

Pan, G., Qiu, S., Liu, X., \& Hu, X. (2015). Estimating the economic damages from the Penglai 19-3 oil spill to the Yantai fisheries in the Bohai Sea of northeast China. Marine Policy, 62, 18-24. doi: https://10.1016/j.marpol.2015.08.007

Phenson, U. A., Ojie, P. \& Esin, J.O. (2014). The Nigerian State, Security Management Mandate and Challenges in the Niger-Delta Region, Nigeria. Journal of Research \& Method in Education (IOSRJRME), 4, 3, 15-20.

Picou, J., Marshall, B., \& Gill, D. (2004). Disaster, litigation, and the corrosive community. Social Forces, 82(4), 1426-1497.

Pourvakhshouri, Seyedeh Zahra (2008). Coastal Priority Ranking in Oil Spill Response Decision Support Mechanism. Thesis Submitted to the School of Graduate Studies, Universiti Putra Malaysia In Fulfilment of the Requirements for the Degree in Doctor of Philosophy.

Psarros, G., R. Skjong, \& E. Vanem (2011). Risk acceptance criterion for tanker oil spill risk reduction measures. Marine Pollution Bulletin, 62(1), 116-127.

Ramseur, Jonathan. L. (2012). Oil Spills in U.S. Coastal Waters: Background, Governance, and Issues for Congress. CRS Report for Congress, 1-28. 
https://www.epw.senate.gov/public/_cache/files/d/b/db4335ea-2eac-4e97-b37d7bb90bb4b165/01AFD79733D77F24A71FEF9DAFCCB056.crs-oilspills043010.pdf

Ritchie, B. W., Crotts, J. C., Zehrer, A., \& Volsky, G. T. (2013). Understanding the Effects of a Tourism Crisis. Journal of Travel Research, 53(1), 12-25. doi: https://10.1177/0047287513482775

Sabet, S. A. H., Cam, M.-A., \& Heaney, R. (2012). Share market reaction to the BP oil spill and the US government moratorium on exploration. Australian Journal of Management, 37(1), 61-76.

Smith, L. C., Smith, M., \& Ashcroft, P. (2010). Analysis of Environmental and Economic Damages from British Petroleum's Deepwater Horizon Oil Spill. SSRN Electronic Journal. doi: https://10.2139/ssrn.1653078

Sofiri Joab-Peterside (2007). Niger Delta Economies of Violence: Working Paper No. 21 On the Militarization of Nigeria's Niger Delta: The Genesis of Ethnic Militia in Rivers State, Nigeria Research Fellow Center for Advanced Social Science (CASS) Port Harcourt, Nigeria. https://pdfs.semanticscholar.org/f317/3bd949385a63af269f12a2f7dd83eb67d7e2.pdf

Steiner, J. F., \& Steiner, G. A. (2012). Business, government, and society: A managerial perspective, text and cases $\left(13^{\text {th }}\right.$ ed.). New York: McGraw-Hill/ Irwin.

Steiner, Richard (2010). Double standard: Shell Practices in Nigeria Compared with International Standards to Prevent and Control Pipeline Oil Spills and the Deepwater Horizon Oil Spill. This report is written on behalf of: Friends of the Earth Netherlands.

http://oasisearth.com/Resources/Milieudefensie\%20rapport\%20Shell\%20Double\%20Standard\%20L\% 2010-50-4435\%20LR.pdf

Tashakkori, A \& Teddlie, C, (1998). Mixed Methodology Combining Qualitative and Quantitative Approaches. Thousand Oaks, CA, Sage Publications.

Teddlie, C. \& Tashakkori, A. (2009). Foundations of mixed methods research: Integrating quantitative and qualitative approached in the social and behavioral sciences. London: SAGE.

Taleghani, N. D., \& Tyagi, M. (2017). Impacts of Major Offshore Oil Spill Incidents on Petroleum Industry and Regional Economy. Journal of Energy Resources Technology, 139(2), 022913. doi: https://10.1115/1.4035426

Wang Y-C (2011). Short-and Long-run Environmental Kuznets Curve: Case Studies of Sulfur Emissions in OECD Countries. Online; accessed 12/05/ 2020. Google Scholar 